\section{УПРАВЛІННЯ ПЕРСОНАЛОМ ПІДПРИЕМСТВ ТУРИСТИЧНОЇ ГАЛУЗІ}

\author{
ГУМЕНЮК Г.М., \\ кандидат педагогічних наук, доцент \\ кафедри туризмознавства $i$ \\ краєзнавства,
}

ТКАЧІВСЬКА I.М., кандидат педагогічних наук, доцент кафедри теорії та методики фізичної культури і спорту,

ГУМЕНЮК А.I., асистент кафедри туризмознавства $i$ краєзнавства, Прикарпатський національний університет імені Василя Стефаника (м. Івано-Франківськ)

У статті визначено сучасний стан управління персоналом в туристичному підприємстві. 3 погляду ринкової економіки щодо управління персоналом туристичне підприємство висвітлює людський фактор як надбання організації, як свій ресурс, який повинен ефективно застосовуватись для досягнення основних иілей та очікуваних результатів діяльності. Визначені основні проблеми при здійсненні управління персоналом на туристичному підприємстві. Систематизовано основні принципи управління персоналом, такі як: системність, тобто концептуальне поєднання усіх дій, які зорієнтовані на персонал; цілеспрямованість, тобто певні прочеси управління персоналом, які спрямовані на повночінне досягнення цілей туристичних підприємств; науковість, тобто діяльність туристичних суб'єктів управління спрямована на науково-обтрунтовані методи під час здійснення управління персоналом; оптимальність, яка полягає у відсутності в керівника прагнення до отримання потрібних результатів будь-яким способом та ијіною; послідовність прочесів управління; баланси відповідальності та повноважень, він використовується на всіх рівнях туристичного підприємства; взаємоузгоджене поєднання колективних та особистих інтересів з інтересами туристичного підприємства, дотримання етично-моральних норм, щзо є обов'язковою умовою у взаєминах між персоналом та туристичним підприємством. Розкрито проблеми, які пов'язані з управлінням персоналом в туристичних підприємствах. Гарантією результативного та перспективного управління персоналом є оновлена, гнучка $i$ якісно адаптована до сучасних умов організачійна структура, яка повинна орієнтуватись на збалансування поведінки персоналу та надання відповідної допомоги працівникам туристичного підприємства. Запропоновано комплекс заходів щуодо вдосконалення системи управління персоналом на туристичному підприємстві. У статті виділено основні методи управління персоналом в туристичних підприємствах нашої держави.

Ключові слова: туристична галузь, сфера послуг, управління персоналом, трудові ресурси, методи управління, професіоналізм.

Табл.: 1. Рис.: 1. Літ.: 9. 


\title{
HUMAN RECOURSES MANAGEMENT OF TOURISM ENTERPRISES
}

\author{
HUMENIUK Halina, \\ Candidate of Pedagogical Science, \\ Associate Professor Department of Tourism and Local lore,
}

TKACHIVSKA Inna, Candidate of Pedagogical Science, Associate Professor Department of Theory and Methods of physical Culture and Sports,

HUMENIUK Andriy, Assistant of the Department Tourism and Local Lore, Vasyl Stefannyk Prekarpathian National University (Ivano-Frankivsk)

The article defines the current state of personnel management in a tourist enterprise. From the point of view of market economy in terms of personnel management, the tourism enterprise highlights the human factor as the property of the organization, as its own resource, which must be effectively used to achieve the main goals and expected results. The main problems in the implementation of personnel management at the tourist enterprise are identified. The basic principles of personnel management are studied, such as: systematicity ie the conceptual combination of all actions aimed at personnel; sense of purpose, ie certain processes of personnel management, which are focused on the full achievement of the goals of tourism enterprises; scientific, ie the role of tourism management entities is aimed at science-based methods in the implementation of personnel management; optimality, which consists in the absence of the leader's desire to obtain the needed results in any way and price; sequence of management processes; balance of responsibility and authority, it is used at all levels of the tourism enterprise; mutually agreed combination of collective and personal interests with the interests of the tourist enterprise, observance of ethical and moral norms, which is a background in the relationship between the staff and the tourist enterprise. Problems related to personnel management in tourist enterprises are revealed. The guarantee of effective and long-term personnel management is an updated, flexible and well-adapted to modern conditions organizational structure, which should focus on balancing staff behavior and providing appropriate assistance to employees of the tourist enterprise. A set of measures to improve the personnel management system at the tourist enterprise is proposed. The article highlights the main methods of personnel management in tourism enterprises of our state.

Keywords: tourism industry, services, personnel management, human resources, management and professionalism.

Tabl.: 1. Fig.: 1. Ref.: 9.

\section{УПРАВЛЕНИЕ ПЕРСОНАЛОМ ПРЕДПРИЯТИЙ ТУРИСТИЧЕСКОЙ ОТРАСЛИ}

ГУМЕНЮК Г. М., кандидат педагогических наук, доцент 
ГУМЕНЮК А. И., ассистент кафедры туризмоведения и краеведения, Прикарпатский национальный университет имени Василия Стефаника (2. Ивано-Франковск)

\begin{abstract}
В статье определено существующее положение по управлению персоналом на туристическом предприятии. С точки зрения рыночной экономики по управлению персоналом, туристическое предприятие освещзет человеческий фактор как достояние организации, как свой ресурс, который должен эффективно применяться для достижения основных иелей и ожидаемых результатов деятельности. Определены основные проблемы при осуществлении управления персоналом на туристическом предприятии. Исследованы основные принципь управления персоналом, такие как: системность, то есть кониептуальное сочетание всех действий, направленных на персонал; иелеустремленность, то есть определенные процессы по управлению персоналом, ориентированные на полноценное достижение целей туристических предприятий; научность, т.е. роль туристических субъектов управления, направленная на научно-обоснованные методы при осуществлении управления персоналом; оптимальность, которая заключается в отсутствии у руководителя стремления к получению нужных результатов любым способом и иееной; последовательность прочессов управления; балансы ответственности и полномочий, он используется на всех уровнях туристического предприятия; взаимосогласованное сочетание коллективных $u$ личных интересов с интересами туристического предприятия, соблюдение нравственноморальных норм, что является обязательным условием в отношениях между персоналом и туристическим предприятием. Раскрыты проблемы, связанные с управлением персоналом в туристических предприятиях. Гарантией результативного и перспективного управления персоналом выступает обновленная, гибкая и качественно адаптированная к современным условиям организачионная структура, которая должна ориентироваться на сбалансирование поведения персонала и на предоставление соответствующей помощи работникам туристического предприятия. Предложен комплекс мероприятий по совершенствованию системы управления персоналом на туристическом предприятии. $B$ статье выделены основные методы управления персоналом в туристических предприятиях намего государства.
\end{abstract}

Ключевые слова: туристическая отрасль, сфера услуг, управление персоналом, трудовые ресурсы, методы управления, профессионализм.

Табл.: 1. Рис.: 1. Лит.: 9.

Постановка проблеми. Управління персоналом як науку було створено наприкінці XIX - на початку XX ст. завдяки виникненню великої кількості теорій, загальних ідей та орієнтації суспільного виробництва безпосередньо на людину, на вдосконалення іï навичок, інтелекту, культури мислення, творчих умінь та здібностей, духовних та матеріальних особливостей для подальшого їх зростання. Тобто розвиток усіх напрямків характеру для підвищення 
професійності як управління, так і персоналу.

Повноцінні вивчення та аналіз сфери послуг та інших важливих аспектів, особливо тих, які стосуються управління персоналом, практично не досліджуються, хоча ця проблематика досить актуальна. Основною причиною такої ситуації $\epsilon$ приховування економічної діяльності 3 боку підприємств туристичного бізнесу від стороннього ока. Підприємці остерігаються відкривати отримані дані та прибутки стороннім дослідникам, побоюючись жорсткої конкуренції та іiї наслідків.

Основним фактором конкурентоспроможності туристичних підприємств, їхнього процвітання вважається якість наявного персоналу та його ставлення до праці, рівень професіоналізму та творчого потенціалу співробітників.

Тому саме персонал несе відповідальність за процвітання, особливо коли матеріальні ресурси підприємства $є$ загальнодоступними та достатніми, а застосовані керівництвом технології та методи щодо управління персоналом $\epsilon$ не дуже складними.

Саме завдяки особливим прогностичним якостям, професіоналізму та інтуїції людини в сучасних умовах навколишнього середовища достатньо підвищується результативність та цінність прийнятих рішень. I тому персонал, який має високу кваліфікацію, значні творчі та трудові здібності та достатній рівень самооцінки, потребує відповідного ставлення до себе з боку керівництва. А керівництво такими співробітниками потрібно здійснювати лише за новими та осучасненими методами, не принижуючи їхньої унікальності, знань, умінь та обов'язково змінивши чи оновивши усі ті методи, які вже застаріли для сучасного туристичного світу. Саме тому виникає нагальна потреба у підтримці високого рівня управління та організації праці персоналу в туристичному бізнесі.

Аналіз останніх досліджень i публікацій. Дослідженням проблем методології, теорій та практик з управління персоналом присвячено достатньо велику кількість наукових праць таких авторів, як Балабанова Л.В., Грузіна I.А., Злупко С, Колот А., Орбан-Лембрик Л., Ситник Н., Щекин Г. та ін. Але внаслідок багатоаспектності цієї проблематики та її складнощів у сучасному світі все ще існують невирішені питання.

Формулювання цілей статті. Метою статті $є$ обгрунтування теоретичних засад управління персоналом на туристичних підприємствах та впровадження комплексу заходів щодо вдосконалення системи управління працівників туристичних закладів.

Виклад основного матеріалу дослідження. Одним із важливих напрямів у системі управління є люди (трудові ресурси), з відповідним рівнем освіти, майстерністю та досвідом. Досить значна кількість визначень стосовно людей, які працюють на туристичних підприємствах, діє саме в теоріях менеджменту: людський фактор, персонал, трудові ресурси, кадри. Але найбільш точним та повним вважається поняття «персонал», оскільки воно більш повноцінно роз'яснює значення особового складу туристичного підприємства i $€$ відповідальним по найму, а також містить певні ознаки, до яких входять: а) 
робочі відносини з роботодавцями, що затверджуються спеціальними трудовими договорами; б) поєднання організаційних та особистих напрямів та наявність позитивних якісних характеристик.

3 погляду ринкової економіки щодо управління персоналом туристичне підприємство висвітлює людський фактор як надбання організації, як свій ресурс, який повинен ефективно застосовуватись для досягнення основних цілей та очікуваних результатів діяльності. Саме через це в сучасному світі основним завданням управління персоналом вважається правильне поєднання різноманітних стажувань працівників, підвищення їхньої кваліфікації, трудових мотивацій для повноцінного розвитку їхніх навичок та вмінь, а також всебічне стимулювання співробітників щодо виконання поставлених завдань високого рівня. Тому й сам персонал туристичного підприємства повинен постійно бути зорієнтованим на підвищення свого культурного та освітнього рівнів [5].

Для ефективного управління персоналом варто використовувати спеціальні принципи для уникнення усіх можливих ризиків і для збереження престижу туристичного підприємства.

На етапі наукового дослідження Ситник Н. І. виділяє такі принципи управління персоналом: 1) системність, тобто концептуальне поєднання усіх дій, спрямованих на персонал; 2) цілеспрямованість, тобто певні процеси управління персоналом, які зорієнтовані на повноцінне досягнення цілей туристичних підприємств; 3) науковість, тобто роль туристичних суб'єктів управління спрямована на науково-обгрунтовані методи під час здійснення управління персоналом; 4) оптимальність, яка полягає у відсутності в керівника прагнення до отримання потрібних результатів будь-яким способом та ціною; 5) послідовність процесів управління, тобто затверджені методи та процедури управління, встановлені норми та правила щодо взаємовідносин на туристичному підприємстві не повинні мати суперечливостей; 6) баланси відповідальності та повноважень, які використовуються на всіх рівнях туристичного підприємства, тобто від працівника найнижчої посади (в управлінській структурі) до керівника (директора); 7) взаємоузгоджене поєднання колективних та особистих інтересів 3 інтересами туристичного підприємства, яке виявляється у тому, що незалежно від прагнення досягти якнайшвидше своїх цілей, підприємство не нехтує інтересами, потребами та цілями окремого співробітника і спрямовує свої дії на зникнення різноманітних конфліктів у трудовому колективі; 8) дотримання етично-моральних норм, що $\epsilon$ обов'язковою умовою у взаєминах між персоналом та туристичним підприємством [7].

Тому управління персоналом характеризується як певний процес щодо реалізації кадрової політики за допомогою управлінських впливів керівництва, співробітників кадрової служби чи інших суб'єктів туристичної галузі, який спрямовується на оцінку, мотивацію, стимулювання, відбір, пошук, чи розвиток персоналу.

Серед основних методів управління персоналом ми виділяємо: 
- $\quad$ планування, прогнозування та облік робіт із персоналом;

- $\quad$ стимулювання та мотивацію ділової активності на підприємстві

- $\quad$ найм та рекрутинг (залучення) персоналу;

- $\quad$ оптимізація умов праці та трудових відносин на підприємстві;

- управління кар'єрою, розвитком та вивільненням співробітників;

соціальна, економічна та консультативна).

Усі ці методи повинні бути тісно пов'язаними на підприємстві, діяти злагоджено, розплановано та застосовуватись лише тим керівником, у якого $\epsilon$ високий професійний рівень.

Такі методи управління, як планування, прогнозування й обік роботи 3 персоналом можуть значно підвищити якість і результативність туристичного підприємства загалом, якщо правильно їх застосовувати або спрямовувати на відстеження певних змін у професійно-управлінській структурі персоналу та на аналізі тенденцій розвитку персоналу, тобто вчасно ставити до них кількісні та якісні вимоги.

У сучасних умовах сильної ринкової конкуренції успішність діяльності туристичного підприємства першочергово залежить від творчого потенціалу працівників, а найголовнішим завданням професійного менеджера 3 туризму $\epsilon$ мотивування персоналу.

Методи стимулювання та мотивації ділової активності на підприємстві застосовуються для стимулювання матеріальної зацікавленості персоналу або окремого працівника в досягненні позитивних результатів діяльності, тобто в отриманні того остаточного результату, який вміло забезпечить зацікавленість обох сторін. Вони можуть будуть ефективними лише в тих випадках, коли управлінські органи будуть підвищувати і підтримувати той рівень праці, який вони оплачують.

Сучасні механізми мотивації праці на території країни залишаються неефективними та застарілими, вони не відповідають основним потребам сучасного світу та стратегічним завданням економічного розвитку держави. Проблеми в управлінні персоналом викликають незручності не тільки в керівництва, а й у працівників. Тому управління персоналом і $є$ найголовнішим аспектом для ефективної діяльності туристичних підприємств. Аналіз наукової літератури дає можливість визначити основні проблеми при здійсненні управління персоналом на туристичному підприємстві (рис. 1) [8].

1. Проблема відмінника. Дуже часто на посаду керівника призначається найкращий працівник. У зв'язку з цим існує велика кількість керівників, які володіють тільки тими знаннями, які стосуються їхньої сфери, а також тих, які лише поверхово можуть мати знання про технологію управління персоналом. Інформацію про технологію та методи щодо управління персоналом ці керівні посадові особи отримують завдяки спостереженню за своїми керівниками чи використовуючи чужу практику, наприклад при перегляді документальних фільмів схожої тематики. I, як висновок, на практиці з'ясовується, що таких 
знань недостатньо для ефективного управління персоналом через постійне допускання ними помилок.

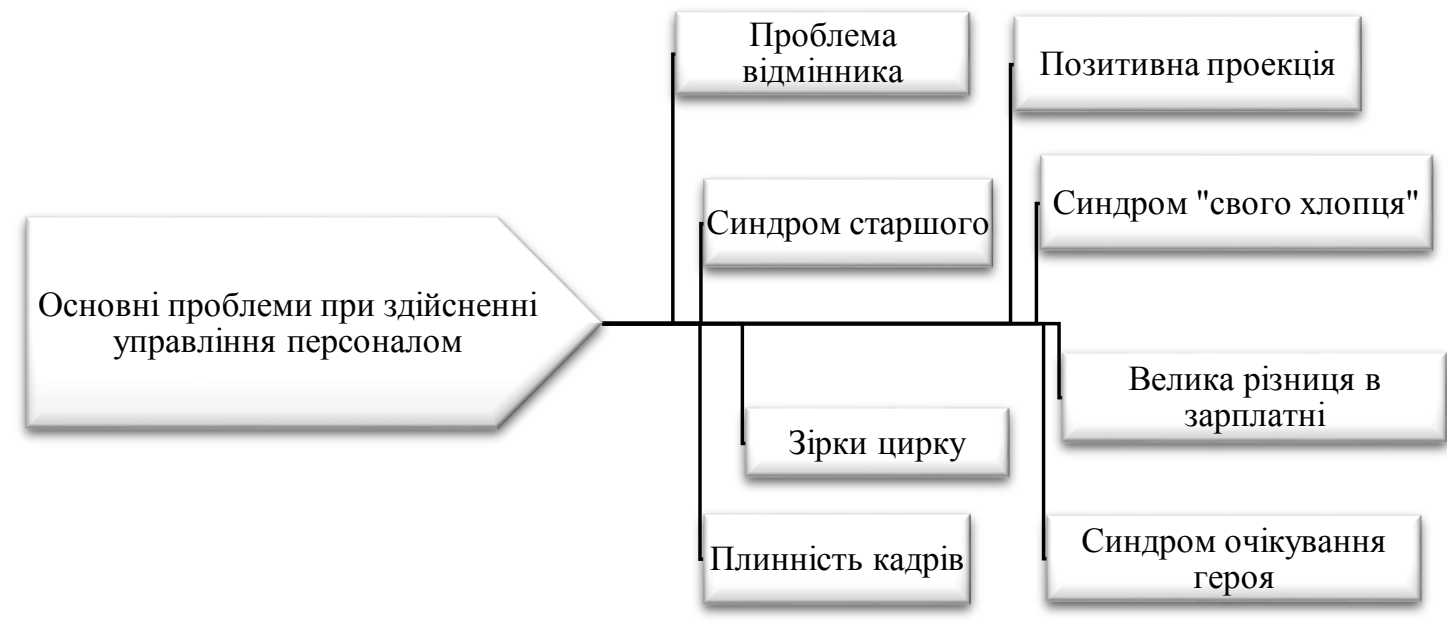

Рис. 1. Основні проблеми при здійсненні управління персоналом на туристичному підприсмстві

Джерело: складено на основі [2, 6]

2. Синдром старшого. Працівники туристичного підприємства досить часто та занадто пильно спостерігають за керівником. Тому є велика кількість директорів, які використовують підтримування дистанції зі співробітниками. Через це керівник туристичного підприємства може зберігати своє посадове місце тільки завдяки жостким принципам.

3. Позитивна проєкція. Це певні бажання та прагнення до приписування іншим особам своїх особистих рис характеру. Таким людям набагато простіше i зручніше уявити, що вони зробили б у певній ситуації, ніж здійснювати аналіз або прогнозування розвитку можливих подій, тобто це повністю неправильна поведінка. Через досить серйозне ставлення до роботи керівники багатьох туристичних підприємств сподіваються, що працівник, виконуючи поставлені перед ним завдання, буде реалізовувати велику кількість умінь та навичок, творчих здібностей, старанності та зробить усе якісно, хоча й забувають про характерні особливості кожного робітника.

4. Синдром «свого хлопця» полягає в застосуванні керівниками певних конфронтаційних методів управління стосовно працівників. Але не всім співробітникам подобається додаткова робота, що часто створює для них нові незручності чи проблеми. Тоді керівник намагається подолати негатив та опір 3 боку працівників, що викликає багато конфліктних і стресових ситуацій на туристичних підприємствах.

5. Зірки цирку. На багатьох підприємствах трапляються ситуації, коли керівники вважають, що кожен працівник, отримуючи високу заробітну плату, повинен здійснювати наднормову працю та сильно перенавантажуватись.

6. Плинність кадрів. Контролювати плинність кадрів на туристичному 
підприємстві обов'язково потрібно, якщо керівництво має за мету уникнути неефективного розподілу праці та неправильного формування співробітників. Хоча на сучасних підприємствах туристичного бізнесу нечасто відбувається найм молодих та нових фахівців. Тобто досить велика кількість висококваліфікованих людей залишаються безробітними.

7. Велика різниця в зарплатні між працівниками та керівництвом. В Україні розмір цієї різниці досить великий - вище $55 \%$, коли на заході ця різниця дорівнює лише близько $30 \%$.

8. Синдром очікування героя. За наявності на підприємстві великої кількості претензій та скарг, які висуваються керівництвом стосовно співробітників, можна побачити певну закономірність щодо очікування героя, який здатен повноцінно вирішити усі наявні проблеми завдяки своїм сильним сторонам та кмітливості. Герой, який здатен лише одним поглядом на обличчя керівника зрозуміти, що саме потрібно з'ясувати та який завжди вчасно виконує усі завдання, знаходить додаткову роботу на підприємстві, не ставить непотрібних запитань, який ніколи не розраховує на підвищення та який може затриматись на роботі навіть до пізньої ночі.

Наведені вище сучасні основні проблеми щодо здійснення управління персоналом свідчать про наявність у туристичних організаціях певних своїх правил. А також після аналізу наведених аспектів стає зрозумілим, що предметом кадрового менеджменту $є$ ефективність діяльності персоналу. Тому керівник-професіонал туристичного підприємства має ставити за мету виявлення усіх можливих проблем управління персоналом, проаналізувати їх та уникнути в майбутньому їхнього повторення.

Найголовнішою $є$ проблема обмеженого розуміння соціальних ролей підприємства та його працівників. Суть цієї проблеми полягає у відсутності взаєморозуміння між працівниками та керівниками, що виявляється у відсутності на туристичному підприємстві довгострокових та чітких цілей, а також узгоджених стратегій щодо їхнього досягнення. Нерозуміння окремими працівниками своєї соціальної ролі та неприйняття повної відповідальності за свої дії часто призводить до конфліктів інтересів соціальних груп, які хочуть поліпшити своє становище за рахунок інших груп чи цілого суспільства. Такі ситуації можна пояснити двома причинами:

-персонал досі часто використовують як трудові витрати, які потрібно скорочувати, а не як основні ресурси, розвиток та професійне управління яким може визначити успіх усього туристичного підприємства;

-керівництво доволі часто не розуміє мотивів поведінки співробітників.

Тому при неусвідомленні соціальних ролей туристичних підприємств, досить проблематично правильно виявляти позитивні соціальні ефекти. Окрім цього, через відсутність чітко сформованих орієнтирів для розвитку, керівник досить часто займається виконанням поточних завдань, а не зосереджується на реалізації стратегій туристичного підприємства, що негативно впливає на здійснення важливих заходів, ефект від яких виявляється повільно. 
Наступна група проблем полягає у сприйнятті персоналу в ролі основних ресурсів туристичних підприємств, що також виявляється як нерозуміння відмінностей між людськими та іншими видами ресурсів. Адже специфіка щодо сприймання трудових (людських) ресурсів визначається емоційною реакцією працівників на зовнішні впливи, а також на різноманітні методи впливу на персонал.

До важливих особливостей людських ресурсів, які значно підвищують увагу до ефективності їхнього застосування, відносять:

- можливість довготривалої співпраці туристичного підприємства і його співробітників;

- здатність працівників до якісного та постійного самовдосконалення.

Не потрібно також забувати про проблему ігнорування певних цілей працівників, які приходять на туристичні підприємства, щоб повністю реалізувати свої можливості та творчі здібності. Тому процес взаємодії між співробітниками та туристичним підприємством повинен бути двостороннім, а також повноцінна задоволеність з боку працівника цією взаємодією чи роботою, що $є$ необхідним для подальших хороших робочих стосунків та для позитивної діяльності туристичного підприємства [1].

Завершальною проблемою, яка досить часто виникає на туристичних підприємствах, є слабка здатність керівників стосовно визначення основних мотивів поведінки співробітників, а також їхніх потреб та особистих (робочих) проблем, або відсутність належної уваги до працівників, що може призводити до руйнування різних їхніх очікувань та повного незадоволення. Ці ситуації пояснюють наявні на туристичних підприємствах труднощі та проблеми, тобто демонструють стереотипи персоналу, пасивну їхню поведінку, нерозвиненістю системи мотивування, або непрофесійною трудовою діяльністю, хоча причина полягає в тому, що співробітник просто налаштований на отримання усіх благ від туристичного підприємства, а не сам, своїми силами, був направлений на заробляння коштів та доведення своєї цінності керівнику. Такі працівники $є$ важко керованими, вони практично не піддаються мотиваційним впливам.

У сучасних туристичних підприємствах України системи підвищення професійної підготовки і навчання робітників належним чином не фінансують. Тому рівень освіти, вік, стаж співробітників цих підприємств, а також рівень оплати праці персоналу не можуть повністю відповідати основним завданням реалізації сучасної кадрової політики. Через наявність економічних тенденцій у нашій країні для впровадження нових форм та сучасних методів управління персоналом дуже важливою $є$ проблема вдосконалення цього управління.

Тому в сучасних складних для України умовах змінного та важко регульованого споживчого ринку на туристичних підприємствах обов'язково повинні проводитись такі заходи:

-організація ефективної діяльності співробітників;

-розміщення працівників відповідно до їхніх завдань, вмінь (навичок), кваліфікаційних рівнів та здібностей; 


\section{EФМ}

http://efm.vsau.org/

-повноцінне контролювання умов праці;

-знане підвищення ролі навчання співробітників;

-організація усіх видів професійної перепідготовки, підготовки та підвищення кваліфікаційних рівнів, яка повністю базується на індивідуальних вимогах та потребах працівників [2].

Гарантією результативного та перспективного управління персоналом $\epsilon$ оновлена, гнучка і якісно адаптована до сучасних умов організаційна структура, яка повинна орієнтуватись на збалансування поведінки персоналу та на надання відповідної допомоги працівникам туристичного підприємства.

Часто на туристичних підприємствах наявні проблеми 3 управлінням персоналом, які повністю залежать від застосованих функцій стосовно робітників, тому що вони розподіляються між різними підрозділами: відділ організації праці та заробітних плат, відділ кадрів, відділ техніки безпеки, тому на таких туристичних підприємствах ніхто конкретно не займається якісним використанням трудових потенціалів робітників [9].

Покращення функцій відносно управління персоналом 3 економічного погляду може значно прискорити зростання ефективності роботи туристичних підприємств. А в соціальних аспектах значні зміни в цілій системі управління персоналом мають спрямовуватись на максимально корисне застосування та розвиток вмінь (навичок, здібностей) усіх найнятих робітників туристичного підприємства, а також на забезпечення сприятливих умов для тих клієнтів, які користуються послугами, надані цим підприємством [3].

Оновлення цієї системи управління полягає в якісному осучасненні організаційних структур, створенні нових систем цінностей, ідеологій, зміні принципів мотивування та стилів управління. Зосереджуючись на сучасних та нових принципах управління персоналом, обов'язково мають бути розроблені певні проєкти щодо змін усіх структур управління, наявних технічних засобів, інформаційних систем.

Зважаючи на це, найважливішою та найпотрібнішою складовою кожної організаційної системи $є$ дотримання порядку та дисципліни, що вважається дуже зручним способом щодо максимізації застосування трудових ресурсів на туристичному підприємстві [6].

Удосконалення системи управління персоналом буде ефективним при реалізації таких завдань:

-застосовувати спеціальну програму розвитку та навчання персоналу, що значно підвищить соціальну та економічну ефективності щодо діяльності туристичного підприємства, а також зможе вплинути на покращення якості обслуговування кліснтури;

- розробляти системи нематеріальної та матеріальної мотивацій та організовувати цілу систему забезпечення якості надання медичної допомоги з іiі стандартизацією, що вплине на зменшення плинності кадрів і максимально забезпечить зростання якості та обсягів послуг, які надаються;

- здійснювати реалізацію спеціально-створених програм 3 підвищення 
рівнів задоволеності працею працівників на робочих місцях, формувати певні мотиви для досягнення цілей, що дозволять якісно підтримувати мотивування працівників на потрібному рівні;

- удосконалювати наявну організаційну структуру, що також створить спеціальні можливості для пошуку осіб із потрібним способом мислення, які готові віддавати багато сил, які мають відповідальне ставлення до роботи, хочуть працювати та досягати високих робочих цілей, а також це якісно вплине на зростання довіри у підлеглих до керівників;

- упроваджувати розроблені та узгоджені технології щодо управління персоналом, що позитивно вплине на індивідуальну продуктивність персоналу та на показники якості надання підприємством туристичних послуг;

- розробити систему заходів стосовно адаптації нових працівників до роботи в туристичних організаціях, які виявлятимуться на відбиранні найкращих робітників, на створенні спеціальних умов для зручного їхнього входження в трудовий колектив та на швидке підвищення робочих показників, які $\epsilon$ необхідними на підприємстві (табл. 1).

Таблиия 1

Комплекс заходів щодо вдосконалення системи управління персоналом на туристичному підприсмстві

\begin{tabular}{|c|c|c|}
\hline Комплекс заходів & $\begin{array}{c}\text { Вплив на } \\
\text { економічний стан } \\
\text { підприємства }\end{array}$ & $\begin{array}{c}\text { Вплив на якість } \\
\text { обслуговування } \\
\text { клієнтів }\end{array}$ \\
\hline Упровадження програм навчання та розвитку працівників & + & + \\
\hline $\begin{array}{l}\text { Розроблення системи нематеріальної та матеріальної } \\
\text { мотивації }\end{array}$ & + & + \\
\hline $\begin{array}{l}\text { Організація системи забезпечення якості надання медичної } \\
\text { допомоги з іï стандартизацією }\end{array}$ & + & + \\
\hline $\begin{array}{l}\text { Реалізація програм з підвищення рівня задоволеності } \\
\text { працею, формування мотивів для досягнення цілей }\end{array}$ & + & + \\
\hline $\begin{array}{l}\text { Упровадження розроблених технологій управління } \\
\text { персоналом: документаційне забезпечення управління } \\
\text { персоналом, організація праці, система оцінювання } \\
\text { персоналу, система атестації персоналу, система оплати } \\
\text { праці, корекція соціально-психологічного клімату }\end{array}$ & + & - \\
\hline $\begin{array}{l}\text { Система заходів для адаптації нових працівників до роботи } \\
\text { на туристичному підприємстві і в трудовому колективі }\end{array}$ & - & + \\
\hline $\begin{array}{l}\text { Створення нових або оновлення туристичних послуг } 3 \\
\text { орієнтацією на споживчий ринок }\end{array}$ & - & + \\
\hline
\end{tabular}

Джерело: складено автором на основі [1, 6]

Тому для ефективного ведення туристичного бізнесу на підприємствах необхідна повна концентрація праці з управління робітниками лише в одному управлінському відділі, що дасть можливість раціонально та якісно застосовувати потенціал усіх працівників. Це позитивно впливатиме і на значне підвищення координування усіх функцій, які пов'язані з персоналом та може повноцінно розширити кількість наявних завдань відділів управління персоналом, через що вони будуть переходити від певних кадрових питань до планування та створення системи мотивування трудового колективу, вивчення 
вмінь та навичок співробітників, управління кар'єрним зростанням, аналізу та вивчення ринку праці, визначення поточних та перспективних потреб або проблем персоналу, до забезпечення сприятливого психологічно-соціального клімату на туристичному підприємстві [3].

Висновки. У сучасному світі все частіше трапляється інформація про зростання ролі персоналу туристичного підприємства в його позитивній та успішній праці. Через це у великої кількості українських туристичних підприємствах $є$ проблеми, які пов'язані з управлінням персоналом. Від способів вирішення усі наявних проблем залежить майбутнє існування не тільки багатьох туристичних підприємств, а й усієї української економіки. Тому в сучасних складних для України умовах змінного та важко регульованого споживчого ринку на туристичних підприємствах обов'язково повинні проводитись такі заходи: 1) організація ефективної діяльності співробітників; 2) розміщення працівників відповідно до їхніх завдань, вмінь (навичок), кваліфікаційних рівнів та здібностей; 3) повноцінне контролювання умов праці; 4) значне підвищення ролі навчання співробітників; 5) організація усіх видів професійної перепідготовки, підготовки та підвищення кваліфікаційних рівнів, яка повністю базується на індивідуальних вимогах та потребах працівників.

Тому для ефективного ведення туристичного бізнесу на підприємствах необхідна повна концентрація праці з управління робітниками лише в одному управлінському відділі, що дасть можливість раціонального використання потенціалу усіх працівників. Це позитивно впливатиме і на значне підвищення координування усіх функцій, які пов'язані з персоналом та може повноцінно розширити кількість наявних завдань відділів управління персоналом, через що вони будуть переходити від певних кадрових питань до планування та створення системи мотивування трудового колективу, вивчення вмінь та навичок співробітників, управління кар'єрним зростанням, аналізу та вивчення ринку праці, визначення поточних та перспективних потреб або проблем персоналу.

\section{Список використаних джерел}

1. Балабанова Л. В. Управління персоналом. Київ: ЦУЛ, 2011. 468 с.

2. Грузіна I. А. Проблеми розвитку персоналу в системі стратегічного управління підприємством : монографія. Харків: ХНЕУ ім. С. Кузнеця, 2014. 252 c.

3. Колот А. М. Соціально-трудові відносини: теорія і практика регулювання : монографія. Київ: КНЕУ, 2006. 230 с.

4. Марченко О.А., Самокіш А.О., Стребкова К.М. Особливості управління персоналом у сфері туризму та готельно-ресторанному господарстві. URL: http://www.market-infr.od.ua/journals/2018/17_2018_ukr/30.pdf (дата звернення: 20.06.2020).

5. Орбан-Лембрик Л. Е. Основи психології управління: монографія. Івано-Франківськ : Плай, 2010. 426 с.

6. Ситник Н.І. Управління персоналом : навчальний посібник для ВНЗ. 
Київ : Інкос, 2009. 472 с.

7. Соболев В. Г. Технологии эффективного управления персоналом. Управління розвитком. 2011. № 21 (118). С. 162-164.

8. Тютлікова В. В. Розвиток технологій управління трудовим потенціалом персоналу на демократичних засадах. Управління розвитком. 2010. № 6 (82). С. 116-121.

9. Харасова А.С., Блаженкова Н.М. Технология принятия управленческих решений в теории и практике менеджмента. Лидерство $u$ менеджмент, 2015. Том 2. № 2. С. 99-110. - doi: 10.18334/lim.2.2.598

\section{References}

1. Balabanova, L. V. (2011). Upravlinnia personalom [Management a personnel]. Kyiv: TsUL, 468 [in Ukrainian].

2. Hruzina I. A. (2014) Problemy rozvytku personalu $v$ systemi $\approx$ stratehichnoho upravlinnia pidpryiemstvom : monohrafiia [Problems of development of personnel are in the system of strategic management an enterprise]. Kharkiv: KhNEU im. S. Kuznetsia, 252 [in Ukrainian].

3. Kolot A. M. (2006). Sotsialno-trudovi vidnosyny: teoriia i praktyka rehuliuvannia: monohrafiia [Sociallabour relations: theory and practice of adjusting]. Kyiv: KNEU, 230 [in Ukrainian].

4. Marchenko O.A., Samokish A.O., Strebkova K.M. Features of personnel management in the field of tourism and hotel and restaurant industry. Retrieved from: http://www.market-infr.od.ua/journals/2018/17_2018_ukr/30.pdf

5. Orban-Lembryk L. E. (2010). Osnovy psykholohii upravlinnia [Bases of management psychology]. Ivano-Frankivsk : Plai, 426 [in Ukrainian].

6. Sytnyk N.I. (2009). Upravlinnia personalom: navchalnyi posibnyk dlia VNZ [Management a personnel]. Kyiv : Inkos, 472 [in Ukrainian].

7. Sobolev V. H. (2011). Tekhnolohyy effektyvnoho upravlenyia personalom [Technologies for effective personnel management]. Upravlinnia rozvytkom - Development management, 6 (82), 162-164 [in Ukrainian].

8. Tiutlikova V. V. (2010). Rozvytok tekhnolohii upravlinnia trudovym potentsialom personalu na demokratychnykh zasadakh [Development of technologies for managing the labor potential of staff on a democratic basis]. Upravlinnia rozvytkom - Development management. 6 (82), 116-121 [in Ukrainian].

9. Kharasova A.S., Blazhenkova N.M. (2015) Tekhnolohyia pryniatyia upravlencheskykh reshenyi v teoryy y praktyke menedzhmenta [Management decision making technology in management theory and practice]. Lyderstvo i menedzhment Leadership and management. 2(2), 99-110. - doi: 10.18334/lim.2.2.598 [in Ukrainian].

\section{Відомості про авторів}

ГУМЕНЮК Галина Михайлівна - кандидат педагогічних наук, доцент кафедри туризмознавства i краєзнавства, Прикарпатський національний університет імені Василя Стефаника (76019, м. Івано-Франківськ, 


\section{EФМ}

http://efm.vsau.org/

вул. Набережна, буд.4А, кв. 26, e-mail: humenyukgalina@gmail.com).

ТКАЧІВСБКА Інна Михайлівна - кандидат педагогічних наук, доцент кафедри теорії та методики фізичної культури і спорту, Прикарпатський національний університет імені Василя Стефаника (76019, м. Івано-Франківськ, вул. Двірська, буд.22, кв. 69, e-mail: inna.tkachivska@ gmail.com).

ГУМЕНЮК Андрій Ігорович - асистент кафедри туризмознавства i краєзнавства, Прикарпатський національний університет імені Василя Стефаника (76019, м. Івано-Франківськ, вул. Галицька, буд. 66а, кв.68, e-mail: a.humenyuk69@gmail.com).

HUMENIUK Halina - Candidate of Pedagogical Science, Associate Professor Department of Tourism and Local lore, Vasyl Stefannyk Prekarpathian National University, Ivano-Frankivsk (76019, Ivano-Frankivsk, Naberegna st. 4A/ 26, e-mail: humenyukgalina@gmail.com).

TKACHIVSKA Inna - Candidate of Pedagogical Science, Associate Professor Department of Theory and Methods of physical Culture and Sports, Vasyl Stefannyk Prekarpathian National University, Ivano-Frankivsk (76019, Ivano-Frankivsk, Dvirska st. 22/69, e-mail: inna.tkachivska@ gmail.com).

HUMENIUK Andriy - assistant of the department tourism and local lore, Vasyl Stefannyk Prekarpathian National University, Ivano-Frankivsk (76019, IvanoFrankivsk, Galuzka st.66a/68, e-mail: a.humenyuk69@gmail.com).

ГУМЕНЮК Галина Михайловна - кандидат педагогических наук, доцент кафедры туризмоведения и краеведения, Прикарпатский национальный университет имени Василия Стефаника (76019, г. Ивано-Франковск, ул. Набережна, 4A, кв. 26, e-mail: humenyukgalina@gmail.com).

ТКАЧИВСКАЯ Инна Михайловна - кандидат педагогических наук, доцент кафедры теории и методики физической культуры и спорта, Прикарпатский национальный университет имени Василия Стефаника $(76019$, г. Ивано-Франковск, ул. Дворовая, 22, кв. 69, e-mail: inna.tkachivska@ gmail.com).

ГУМЕНЮК Андрей Игоревич - ассистент кафедры туризмоведения и краеведения, Прикарпатский национальный университет имени Василия Стефаника (76019, г. Ивано-Франковск, ул. Галицкая, 66а, кв.68, e-mail: a.humenyuk69@gmail.com). 